\title{
Mechanical dependency of the SARS-CoV-2 virus and the renin-angiotensin-aldosterone (RAAS) axis: a possible new threat
}

\author{
Rohit Sen ${ }^{1} \cdot$ Devashish Sengupta ${ }^{2} \cdot$ Avinaba Mukherjee $^{1}$ \\ Received: 16 April 2021 / Accepted: 1 September 2021 / Published online: 2 December 2021 \\ (C) The Author(s), under exclusive licence to Springer-Verlag GmbH Germany, part of Springer Nature 2021
}

\begin{abstract}
Pathogens in our environment can act as agents capable of inflicting severe human diseases. Among them, the SARS-CoV-2 virus has recently plagued the globe and paralyzed the functioning of ordinary human life. The virus enters the cell through the angiotensin-converting enzyme-2 (ACE-2) receptor, an integral part of the renin-angiotensin system (RAAS). Reports on hypertension and its relation to the modulation of the RAAS are generating interest in the scientific community. This short review focuses on the SARS-CoV-2 infection's direct and indirect effects on our body through modulation of the RAAS axis. A patient having severe acute respiratory syndrome-coronavirus-2 (SARS-CoV-2) infection, which causes COVID-19 relates to hypertension as a pre-existing disease or develops it in a post-COVID scenario. Several studies on how SARS-CoV-2 modulates the RAAS axis indicate that it alters our body's physiological balance. This review seeks to establish a hypothesis on the mechanical dependency of SARS-CoV-2 and RAAS modulation in the human body. This study intends to impart ideas on drug development and designing by targeting the modulation of the RAAS axis to inactivate the pathogenicity of the SARS-CoV-2 virus. A systematic hypothesis can severely attenuate the pathogenicity of the dreadful viruses of the future.
\end{abstract}

Keywords SARS-CoV-2 $\cdot$ Environmental pathogen $\cdot$ ACE2 receptor $\cdot$ RAAS system $\cdot$ Hypertension

\section{Introduction}

The outbreak of COVID-19 due to severe acute respiratory syndrome coronavirus-2 (SARS-CoV-2) has affected millions of people globally, wherein about 3.5 million died due to this outbreak (Dyer 2021; Woolf et al. 2021). However, recent data have suggested that the actual global mortality due to COVID infection is almost 6.9 million (Dyer 2021).

Responsible Editor: Lotfi Aleya

Avinaba Mukherjee

mukherjeeavinaba@gmail.com

Rohit Sen

robikolom1996@gmail.com

Devashish Sengupta

devashish.sengupta@alumni.sydney.edu.au

1 Department of Zoology, Charuchandra College, University of Calcutta, 22, Lake Road, Kolkata 700029, India

2 Department of Chemistry, Assam University, Silchar, Assam 788 011, India
Pathogens like SARS-CoV-2 lead to fatal outcomes, especially in immunocompromised patients infected with the virus (Belsky et al. 2021). Differences in mortality rates among different age groups of the population can be linked with the differential status of the endocrine system, behavioral system, and physiological conditions related to the age groups of the infected human population (Undurraga et al. 2021). The pathogenicity of the coronavirus is attributed to the high affinity of the spike protein that binds with the angiotensin-converting enzyme (ACE)-2 receptors, particularly in the lungs. It is known that ACE2 receptors act as an integral part of an axis termed as the renin-angiotensinaldosterone system (RAAS) (Lavoie and Sigmund 2003; Tikellis and Thomas 2012). There is, therefore, a possibility of modulation of such an essential endocrine axis after COVID infection. Several studies have been made on the impact of COVID on the RAAS axis. However, the current data are scattered in a discrete pattern. In this review, we attempt to summarize the effects of SARS-CoV-2 on the RAAS axis. Also, we have linked the impact of SARS-CoV-2 on RAAS-mediated crosstalk signaling processes such as hypertension and behavioral alteration. 


\section{Effect of SARS-CoV-2 on angiotensin}

The RAAS system has a crucial role in controlling the retention of salts and water in the circulatory system via renal reabsorption, thus regulating blood pressure (Vaduganathan et al. 2020). Angiotensin, specifically Ang II, is the main contributor to the RAAS system by stimulating aldosterone secretion, the main end product of the glomerulosa layer, in the adrenal cortex. Membrane-bound aminopeptidase ACE2 is a regulatory enzyme that cleaves the active form of both angiotensin I and angiotensin II into angiotensin 1-9 and angiotensin 1-7, respectively (Kuba et al. 2010; Strawn et al. 1999; Ye et al. 2006). ACE2 maintains the physiological equilibrium between the vasoconstrictor effect of angiotensin II and thus of angiotensin 1-7, which lowers blood pressure by dilating the blood vessels (Fig. 1) (Burrell et al. 2004). However, its infection by SARS-CoV-2 leads to the disruption of the homeostatic environment devised by RAAS. Measuring blood levels of ACE2 after prospective validation is now known to provide a risk-stratification opportunity, leading to the identification of individuals who are at greater risk of infection or are susceptible to experiencing severe medical complications. An opportunistic approach to protect against the SARS-CoV-2 disease may be possible by targeting the ACE2 system. For an individual patient, this may aid in monitoring responses to preventive measures and treatment interventions. Thus, focusing on the potential therapeutic strategy enabled by targeting ACE2 is especially important.

Autopsies of deceased COVID-19 patients show a remarkable decrease in ACE2 expression (Oudit et al. 2009; Chaudhry et al. 2020) along with severe lung injuries (He et al. 2006), due to inhibition of SARS-CoV-2. Further investigations show a correlation between elevated plasma angiotensin II levels and lung injury along with viral load in severely infected patients (Liu et al. 2020; Miesbach 2020), indicating that ACE2 downregulation promotes angiotensin II. The binding of angiotensin II with AT1 receptors can lead to enhanced inflammation, vasoconstrictors, and thrombosis. On the other hand, angiotensin III is also called as Ang-(2-8). Aminopeptidase A (APA) cleaves the Asp1-Arg2 bond in Ang II and coverts it into Ang III. The major function of Ang III is to regulate hypertension and vasopressin release (Reaux et al. 2001).

AT2R is another important factor in RAAS regulation as both angiotensin II and angiotensin III are modulated after SARSCoV-2 infection. Though AT2R has a significant role in the vasodilation of vascular epithelium AT2R, it lacks any impact in RAAS regulation while $\mathrm{Na}^{+}$excretion through the kidneys increases (Sumners et al. 2015). Angiotensin III might positively affect $\mathrm{Na}^{+}$reabsorption indirectly by interacting with AT2R in the zona pellucida of the adrenals, but the concomitance of the vasodepressor is seen when synthetic $\{$ beta-Pro (7) $\}$ angiotensin III is introduced (Del Borgo et al. 2015). It was earlier reported, due to virus infection, that ACE2 downregulation creates local imbalance between the RAS and ACE2/angiotensin-(1-7)/MAS axis. This might directly lead to severe organ injury. Therefore, the balance between angiotensin I and II, and 1-7 and 1-9, rather than each one alone, may be the main determinant of dysfunctions related to the RAAS (Ni W et al. 2020). As a whole, SARSCoV-2infection-induced modulation in angiotensin and its related receptor expression leads to several altered physiological conditions in the human body.

\section{Possible partial effect of SARS-CoV-2 on aldosterone}

SARS-CoV-2 infection upregulates angiotensin II after binding with the ACE2 receptor (Oudit et al. 2009; Chaudhry et al. 2020) as discussed earlier. On the other hand, angiotensin II upregulates aldosterone secretion (Patel et al. 2017). Therefore, after SARS-CoV-2 infection, there might be a possibility for the elevation of the aldosterone level. However, the reports supporting this are few, but some recent workers have found a positive correlation between upregulated aldosterone levels in COVID-19 patients' bodies (Villard et al. 2020).
Fig. 1 Possible effect of RAAS on blood pressure regulation. Here, ACE2 means angiotensinconverting enzyme 2, AT1R means angiotensin type 1 receptor and AT2R means angiotensin type 2 receptor, $\mathrm{AKKY} \mathrm{C} 1$ means ankyrin $\mathrm{C} 1$ protein, $\mathrm{CK} 1$ means casein kinase 1, and $\mathrm{ENaC}$ means epithelial sodium channel receptor

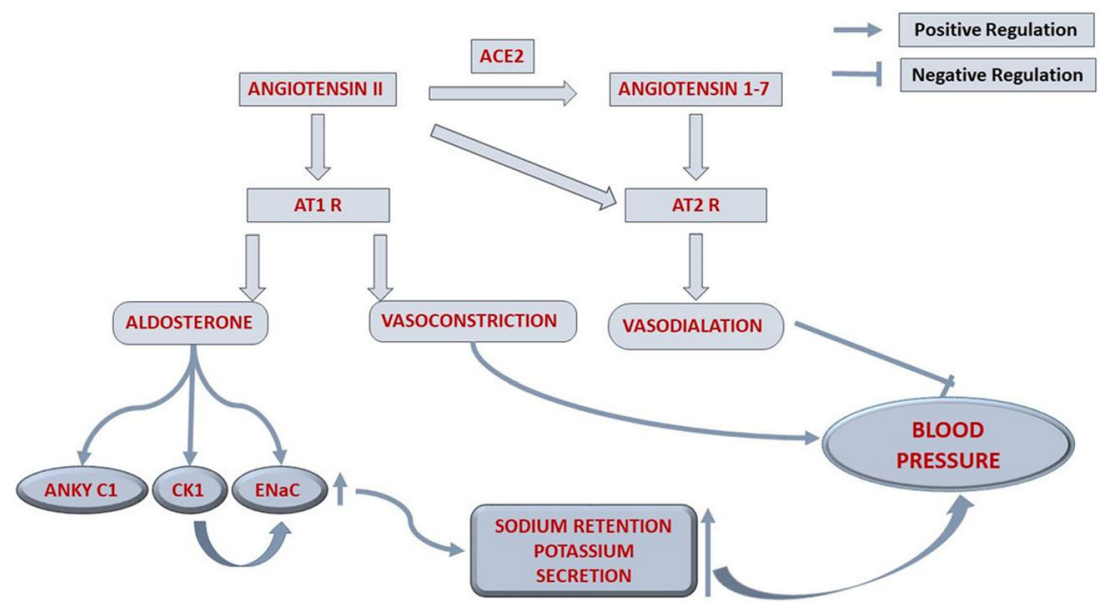


Mineralocorticoids provoke the epithelial sodium channel $(\mathrm{ENaC})$, also called amiloride-sensitive sodium channel, a hetero-trimeric ion channel selectively permeable to sodium ion targeting in the principal cell apical surface (Noreng et al. 2018). Aldosterone facilitates $\mathrm{ENaC}$ function through mediator protein families of casein kinase (CK), ankyrin $\mathrm{G}$ (Klemens et al. 2017), and even circadian rhythm controlling period 1 protein (Gumz et al. 2009). Casein kinase 1 delta/ epsilon, a subtype of $\mathrm{CK}$ protein, though the mechanism is still unclear, triggers ENaC-alpha expression (Yan et al. 2007), i.e., it may act upon the transcriptional level of this protein expression. In several studies, CK1 DELTA/ EPSILON blockage checks ENaC mRNA expression by restricting PER-1 nuclear entry (Richards et al. 2012). Therefore, a SARS-CoV-2-mediated disruption of the RAAS system not only affects the respiratory and cardiovascular systems but also might trigger the regulation of the circadian cycle. This behavioral alteration might be taken into consideration for COVID-19 patients due to elevated aldosterone.

\section{Possible partial effect of SARS-CoV-2 on NO activity and hypertension}

Nitric oxide (NO) is a potent vasodilator; it inhibits the vasoconstriction effects on blood vessels of angiotensin II (Richards et al. 2012). NO not only leads to the reduction of blood pressure by inhibiting the AT1R in the vascular epithelium (Savoia et al. 2020) but also may drive angiotensin II and elevates the interaction of angiotensin II-AT2R. It facilitates the degree of lowering of blood pressure. If administered at the early stages of the infection, NO might play its role in restricting the virus binding to the AT1R in the lungs by hindering AT1R endocytosis of SARS-CoV-2 (Fig. 2).

\section{Modulation of RAAS in other pathological conditions linked with SARS-CoV-2 infection}

RAAS is modulated not only in COVID-19 patients but also in several pathological conditions like obesity, diabetes, inflammations, renal disorders, and others, which might be linked with accentuating the effects of SARS-CoV-2 infection and creating comorbidities and asymptomatic disease in the human population. Obesity is yet another critical factor for disrupting the RAAS axis and elevating the renin (Kalil and Haynes 2012) and aldosterone secretion from the adrenal gland (Peminda et al. 2017; Yang et al. 2021). An adipokine named leptin upregulates renin via sympathetic activation through the CNS (brain stem and hypothalamus) (Peminda et al. 2017; Hall et al. 2010). Along with renin, angiotensin II activity is enhanced either by inhibiting ACE2 (Patel et al.
2016; Soler et al. 2013; Kawabe et al. 2019) or facilitating the conversion of angiotensin I to angiotensin II by cathepsins in adipose tissue (Schütten et al. 2017). This deregulated renin/ angiotensin/aldosterone axis that pre-exists in obese individuals may aggravate COVID-19. Meta-analytic data shows that the susceptibility to infection of COVID-19 increases a few folds in obese individuals than in non-obese individuals, but also obesity aggravates the severity of the condition (Yang et al. 2021; Hall et al. 2015; Zhang et al. 2021) along with it becoming a strong reason for comorbidities.

On the other hand, obesity is strongly associated as a critical feature of diabetes in which high glucose levels induce the release of renin, as reported by Toma et al. (2008). Hyperactivation of the RAAS axis can therefore be observed in diabetic patients (Ribeiro-Oliveira Jr et al. 2008). Hyperactivation of the RAAS axis could consequently help in the invasion of SARS-CoV-2. This observation is supported by some recent data, which shows that diabetic patients are more prone to SARS-CoV-2 infectivity and mortality (Feldman et al. 2020). Besides this, in diabetic patients, monocyte and macrophage activation occur, which creates an elevation of proinflammatory cytokines and chemokines like TNF $\alpha$, IL6, IL8, and others (Kurihara et al. 2012). The heightened proinflammatory cytokines and chemokines create inflammation in the body that might play a vital role in SARS$\mathrm{CoV}-2$ infection, especially in the generation of asymptomatic disease (Xie et al. 2021).

Among the renal abnormalities associated with COVID-19 reports include proteinuria, hematuria, and acute kidney injury. SARS-CoV-2 can infect podocytes, and tubular epithelial cells, contributing to the aforementioned renal abnormalities. The renal abnormalities associated with COVID-19 are related to the rise in the complex multifactorial pathophysiology involving the following: (i) a local disruption in RAAS homeostasis, (ii) a direct cytopathic effect of the virus, and a systemic inflammatory response to infection (Martinez-Rojas et al. 2020). ACE2 supports renal integrity and function through the enzymatic production of angiotensin 1-7 (Ang1-7). Widely expressed ACE2 in proximal epithelial cells, smooth muscle cells, vascular endothelial cells, and podocytes acts as an anti-inflammatory, antifibrotic, vasodilatory, and diuretic/natriuretic agent via activation of the Mas receptor axis. Upon disruption of these activities in the kidneys by ACE2, potential threats of renal damage leading to a high incidence of acute kidney injury (AKI) among SARS-CoV-2 patients are reported (Armaly et al. 2021). The exogenous administration of Ang (1-7) is considered an appealing therapeutic option, given the benefits of ACE2/Ang1-7, including attenuation of inflammation, vasodilation, diuresis, apoptosis, natriuresis, oxidative stress, coagulation, and cell proliferation, as well as the high incidence of AKI in these ACE2-depleted disorders (Martinez-Rojas et al. 2020; Armaly et al. 2021). 


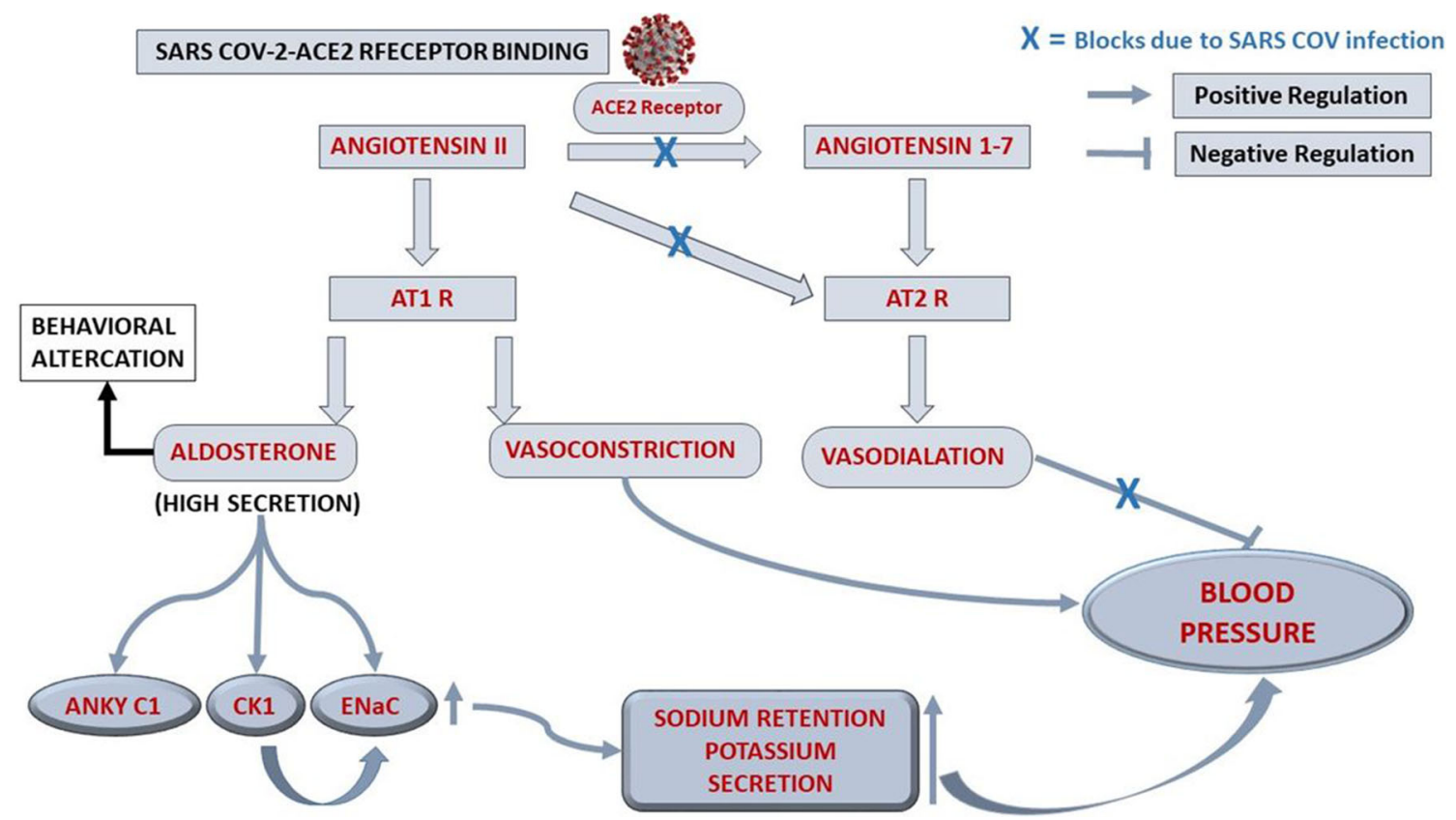

Fig. 2 Possible role of SARS-CoV-2 infection and alteration in the RAAS axis

\section{Drugs that are capable of addressing the alteration in the RAAS axis}

Many drugs have been administered to block the RAAS axis. Some of these drugs are aldosterone receptor antagonist, angiotensin-converting enzyme inhibitors (ACEi), sodium channel blocker, and potassium-sparing channel blocker, among others (Table 1). However, due to the COVID outbreak, the main drug target area has also been modulated so that the pathogen can thrive in the human body and serve its detrimental effect by altering the RAAS axis.

\section{Possible drug target area}

Prompted by the fact that elderly patients with cardiovascular comorbidities have been gravely affected by the severe forms of SARS-CoV-2, interpretations based on retrospective observational studies about the influence of chronic treatment with drugs that are blockers of RAAS are ongoing. However, these retrospective interpretations should be published with caution and only evidence-based data on the impact of RAASinterfering medications in patients and the general population should be published. Under in vivo conditions, reports on 15 classes of drugs in increasing ACE2 levels and a reanalysis of clinical data available from literature from a meta-analysis of 9 studies have shown that an increased risk of mortality is not connected with the usage of ACEIs/ARBs (Akhtar et al. 2020; Kai and Kai 2020; Yehualashet and Belachew 2020). Though research on some animal sources implies enhancing ACE2 expression or activity by drugs against hypertension, data obtained on humans show a contradiction of increased expression of the transmembrane ACE2 protein in the lung brought about by anti-hypertension medications. Cardiovascular conditions can influence the expression of ACE2 in humans, which is independent of RAAS-blockade strategies of treatment (Kai and Kai 2020; Gheblawi et al. 2020; Yehualashet and Belachew 2020). A change in the use of angiotensinconverting enzyme inhibitors (ACEIs) or angiotensin receptor blockers (ARBs) is not required to address the management of elevated blood pressure in the treatment of COVID-19 infection (Gressens et al. 2021). Though it is controversial whether regular usage of these drugs affects ACE2 expression or not, studies showed chronic hypertensive patients tend to have severe symptoms, and hypertension remained one of the main factors for comorbidity (Clark et al. 2021). There is still no evidence for the involvement of elevated ACE2 in plasma levels before infection due to the daily dosage of ARBs and AREs (Ni et al. 2020). Studies show varied responses in patients to ACE2-modulating drugs. Thus, the therapeutic application of such drugs also varied; most of them prescribed persistence of medication. Alternative medication had been devised in cases where AREIs and ARBs show adverse effects (Jarari et al. 2016). Detailed studies on the impact of antihypertensive drugs on ACE2 needed to be done, shedding light on the mechanisms and critical details affecting hypertension.

Since more severe hyper-mutative variants of the COVID19 virus are being identified, alternative approaches exploring the modulation of the specific downstream pathophysiologic effects caused by a virus that leads to morbidity and mortality are being researched (Gressens et al. 2021). Opportunities to understand the various aspects of RAAS inhibitors to alleviate 
Table 1 List of RAAS inhibitors, their structures, and mechanism of action

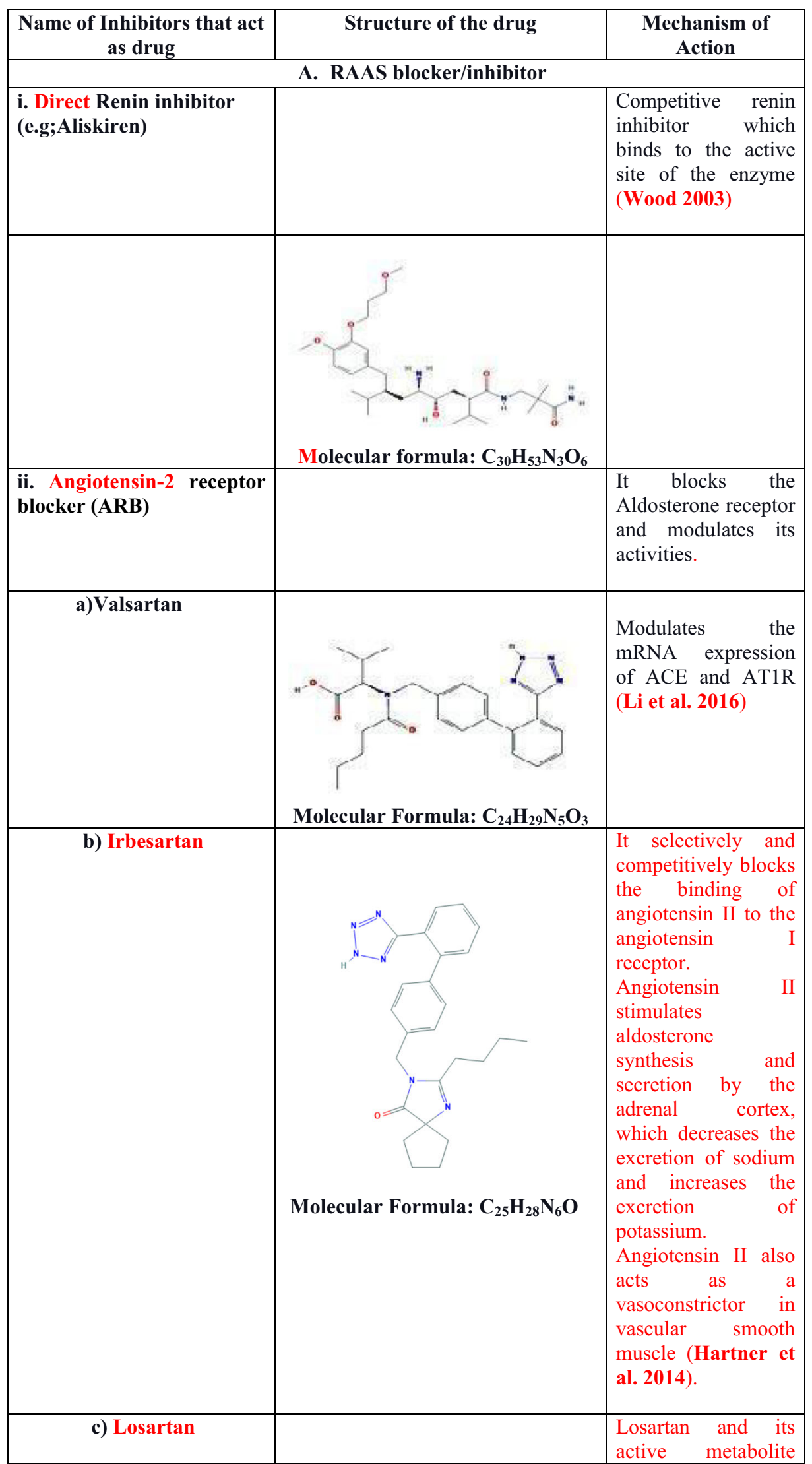




\begin{tabular}{|c|c|c|}
\hline & Molecular Formula: $\mathrm{C}_{22} \mathrm{H}_{23} \mathrm{CIN}_{6} \mathrm{O}$ & $\begin{array}{l}\text { selectively and } \\
\text { competitively block } \\
\text { the binding of } \\
\text { angiotensin II to the } \\
\text { angiotensin I (AT1) } \\
\text { receptor. This blocks } \\
\text { the vasoconstrictive } \\
\text { and aldosterone- } \\
\text { secreting actions of } \\
\text { angiotensin II, } \\
\text { leading to a decrease } \\
\text { in blood pressure. } \\
\text { Angiotensin Irom } \\
\text { formed } \\
\text { angiotensin I by } \\
\text { angiotensin- } \\
\text { converting enzyme } \\
\text { (ACE), stimulates } \\
\text { the adrenal cortex to } \\
\text { synthesize and } \\
\text { secrete aldosterone, } \\
\text { which decreases the } \\
\text { excretion of sodium } \\
\text { and increases the } \\
\text { excretion an af } \\
\text { potassium. } \\
\text { Angiotensin II also } \\
\text { acts as } \\
\text { vasoconstrictor in } \\
\text { vascular smooth } \\
\text { muscle } \\
\text { (Timmermans et al. } \\
\text { 1995). }\end{array}$ \\
\hline $\begin{array}{l}\text { iii. Angiotensin Converting } \\
\text { Enzyme Inhibitor (ACEi) }\end{array}$ & & $\begin{array}{l}\text { Blocks of activation } \\
\text { of Angiotensin- } \\
\text { converting enzyme } \\
\text { and ANG } 1-7 \text { Mas } \\
\text { receptor. }\end{array}$ \\
\hline a) Benazepril & & $\begin{array}{l}\text { It competitively } \\
\text { binds to and inhibits } \\
\text { ACE, thereby } \\
\text { blocking the } \\
\text { conversion of } \\
\text { angiotensin I to } \\
\text { angiotensin II. This } \\
\text { prevents the potent } \\
\text { vasoconstrictive } \\
\text { actions of } \\
\text { angiotensin }\end{array}$ \\
\hline
\end{tabular}




\begin{tabular}{|c|c|c|}
\hline & Molecular Formula: $\mathrm{C}_{24} \mathrm{H}_{28} \mathrm{~N}_{2} \mathrm{O}_{5}$ & $\begin{array}{l}\text { resulting in } \\
\text { vasodilation. } \\
\text { Benazeprilat also } \\
\text { decreases } \\
\text { angiotensin } \\
\text { induced aldosterone } \\
\text { secretion by the } \\
\text { adrenal cortex, } \\
\text { which leads to an } \\
\text { increase in sodium } \\
\text { excretion } \\
\text { subsequently and } \\
\text { increases } \\
\text { outflow (Liu et al } \\
\text { 2011). }\end{array}$ \\
\hline b) Lisinopril (dihydrate) & (N) & $\begin{array}{l}\text { Competitively } \\
\text { inhibits ACE, which } \\
\text { results in a decrease } \\
\text { in the production of } \\
\text { the potent } \\
\text { vasoconstrictor } \\
\text { angiotensin II and, } \\
\text { so, diminished } \\
\text { vasopressor activity. } \\
\text { In addition, } \\
\text { angiotensin } \\
\text { stimulated II- } \\
\text { aldosterone } \\
\text { secretion by the } \\
\text { adrenal cortex is } \\
\text { decreased, which } \\
\text { results in a decrease } \\
\text { in sodium and water } \\
\text { retention and an } \\
\text { increase in serum } \\
\text { potassium (Iyer et } \\
\text { al. 1998). }\end{array}$ \\
\hline c) Enalapril & & $\begin{array}{l}\text { It competitively } \\
\text { binds to and inhibits } \\
\text { ACE, thereby } \\
\text { blocking the } \\
\text { conversion of } \\
\text { angiotensin I to } \\
\text { angiotensin II. This } \\
\text { prevents the potent } \\
\text { vasoconstrictive } \\
\text { actions of } \\
\text { angiotensin II and }\end{array}$ \\
\hline
\end{tabular}




\begin{tabular}{|c|c|c|}
\hline & Molecular Formula: $\mathrm{C}_{20} \mathrm{H}_{28} \mathrm{~N}_{2} \mathrm{O}_{5}$ & $\begin{array}{l}\text { results } \\
\text { vasodilation. } \\
\text { Enalapril } \\
\text { decreases } \\
\text { angiotensin } \\
\text { induced aldosterone } \\
\text { secretion by the } \\
\text { adrenal cortex, } \\
\text { which leads to an } \\
\text { increase in sodium } \\
\text { excretion and } \\
\text { subsequently } \\
\text { increases water } \\
\text { outflow (Hair et al. } \\
\text { 2007). }\end{array}$ \\
\hline \multicolumn{3}{|c|}{ B Epithelial $\mathrm{Na}^{+}$Channel (ENaC) Blocker. } \\
\hline a) Amiloride & Molecular Formula: $\mathrm{C}_{6} \mathrm{H}_{8} \mathrm{CIN}_{7} \mathrm{O}$ & $\begin{array}{lr}\begin{array}{l}\text { Directly } \\
\text { Epithelial }\end{array} & \begin{array}{r}\text { blocks } \\
\text { sodium }\end{array} \\
\text { channels (Kleyman } \\
\text { 1988, Vandenbeuch } \\
\text { 2020). }\end{array}$ \\
\hline \multicolumn{3}{|c|}{ C. $\mathrm{K}^{+}$sparring diuretics } \\
\hline a) Spironolactone & II & $\begin{array}{l}\text { Competitively } \\
\text { blocks } \\
\text { aldosterone } \\
\text { receptors (Layton } \\
2017 \text { ). }\end{array}$ \\
\hline & MolecularFormula: $\mathrm{C}_{24} \mathrm{H}_{32} \mathrm{O}_{4} \mathrm{~S}$ & \\
\hline
\end{tabular}


indirect viral-induced lung and other organ injuries are getting attention (Ingraham et al. 2020). Patients with cardiovascular comorbidities are often administered RAAS blockers. The degree of ACE2 expression in different age groups combating severe infection of the virus and mortality is being hinted at being directly related to the incidence and severity of COVID19 virulence. The benefits or risks of pharmacologic modification of the RAAS-SCoV-axis by drugs that are possible angiotensin-converting enzyme inhibitors (ACEIs) or angiotensin receptor blockers (ARBs) are still not very clear (Gressens et al. 2021). The possibility that these drugs may facilitate viral cell entry has fueled controversies since the expression of ACE2 may be increased by RAAS blockers, yet by degrading angiotensin II into angiotensin, ACE2 functions as a counter-regulator of the RAAS (Gressens et al. 2021). While the former has led to concerns that such modulations may aggravate and worsen the condition of the patients, the latter may mediate beneficial effects in COVID19. The contemporary experimental models through relevant preclinical approaches favor a protective outcome of RAAS$\mathrm{CoV}$-axis inhibition on both lung injury and survival. But there are limitations in clinical data related to the role of RAAS modulation in the setting of SARS-CoV-2. A clinical equipoise regarding the efficacy of RAAS-based interventions and the imminent need for a multisite randomized controlled clinical trial to evaluate the inhibition of the RAAS-SARSCoV-2 axis on acute lung injury in COVID-19 has been proposed (Ingraham et al. 2020). Based on viral microbiology, the target of the various proposed interventions for SARSCoV-2 and the inhibition of viral cellular injury have been proposed (Ingraham et al. 2020).

There is evidence that there may be a relation between ACE2 and the differences in incidence and severity of COVID-19 infection (Kaseb et al. 2021). The prevalence and severity of COVID-19 among the vulnerable groups of patients having age-related comorbidities with established high levels of ACE2 expression establish its candidacy as a potential therapeutic target. Evidence supports the idea that differences in the incidence and severity of COVID-19 infection may be related to ACE2 (Kaseb et al. 2021). The prevalence and severity of SARS-CoV-2 among age- or gender-, or ethnicity-related comorbidity, with established high levels of ACE2 expression, strongly support this inference. The burden of COVID-19 infection in these vulnerable groups added to the impact of the potential therapeutic and preventive measures as a result of adopting ACE2-driven anti-viral strategies; the expedition of a global approach to control the severe infection and mortality of the COVID-19 pandemic may be possible (Kaseb et al. 2021). Though in-depth clinical and mechanistic investigations are still ongoing, literature is indicative of the safety in the usage of ACEIs/ARBs, though, in severe COVID-19 patients, there may be an increased risk of renal injury (Akhtar et al. 2020).
Internalization of ACE2 by SARS-CoV-2 upon entry into the target cell likely reduces cell-surface ACE2 levels, thus translating into (i) the downregulation of Ang-(1-7), (ii) causing unopposed Ang II accumulation, and (iii) RAAS activation promotion (Kaseb et al. 2021). ACE inhibitors and Ang II-receptor blockers as RAAS inhibitors serve as potential therapeutic strategies to prevent SARS-CoV-2 infection. Other options include modifying ACE2 levels or activity in the target cells. As such, the therapeutic approaches for achieving the mentioned options are achievable by blocking spike-protein priming by employing TMPRSS2 inhibitors, slowing the viral entry into target cells by using soluble recombinant ACE2 to competitively bind with the COVID-19 virus serving as a virus trap and inactivator, and developing a vaccine targeting the spike protein of SARS-CoV-2 (Kaseb et al. 2021; Ferrario et al. 2005; Akhtar et al. 2020).

ACE2 is a membrane-bound aminopeptidase. The composition of ACE2 is attributed to a carboxymonopeptidase that prefers hydrolysis between proline and carboxy-terminal hydrophobic residues that is found both as a membraneassociated and as a secreted enzyme in cardiovascular, neuronal, and reproductive organs (Ferrario et al. 2005). Angiotensin I and angiotensin II are cleaved into the angiotensin-(1-9) and angiotensin-(1-7) peptides by ACE2 (Mourad and Levy 2020). ACE2 is overexpressed in heart failure, arterial hypertension, and diabetes mellitus. The existence of a cardiovascularprotective ACE2-angiotensin-(1-7)-Mas receptor axis is supported in several studies (Ferrario et al. 2005). Activation of ACE2 is known to modulate the host and support its replication. Investigations about the role of ACE2 in activating the immune signals on SARS-CoV-2 attachments have prompted the construction of the host regulatory network upon the viral attachment to the ACE2 receptor, specifically in the lungs (Lite et al. 2021). The gene-expression profile of the human lung was integrated with the host regulatory network to investigate the altered host signaling mechanism prevalent in the SARSCoV-2 viral infection. The immune modulation in the constructed network, comprising 133 host proteins with 298 interactions that directly or indirectly connect to the ACE2 receptor, was also determined by functionally enriching the network. Results show that upon infection by SARS-CoV-2, the host lungs differentially regulated 29 proteins out of the 133 host proteins. The generation of a new network of the altered proteins by connecting with multiple proteins was observed to modulate kinase, cytokine, and carboxypeptidase activity. This modulation leads to changes in the host immune system, signal transduction mechanism, and cell cycle. Secondary health complications were apparent from an investigation indicating similar signaling events in the kidneys, pancreas, small intestine, testes, placenta, and adrenal glands (Lite et al. 2021). The interconnected protein hubs are assumed to be activated when the SARS-CoV-2 virus binds with the ACE2 receptor. The direct mediators of these protein hubs were AGT 
(Angiotensinogen), LAMAS (Laminin Subunit Alpha 1), NTS (Neurotensin), GHRL Ghrelin, and (ObestatinPrepropeptide) as revealed by the Interactome data. The association of a regulatory network with various biological pathways responsible for the disease, immune system, DNA repair, cell cycle, autophagy, programmed cell death, transcription, and signal transduction was revealed by the Reactome database (Lite et al. 2021). The presence of ACE2-inducible immune factors across different tissue types was found to be very profound in the lungs compared to other tissues, thus making it more sensitive. The overactive immune response leading to respiratory illness could be an underlying molecular factor (Lite et al. 2021).

ACE2 modulator drugs such as angiotensin-converting enzyme inhibitor (ACEi) though having a suppressing effect on ACE2-induced hypertension and being reported to decrease mortality (Chu et al. 2021) but less likely to be used in patients with a prior chronic medical condition (like hypertension, diabetes mellitus, cardiovascular disease) may show unlike effects (Fang et al. 2020). In contrast to $\mathrm{Na}^{+}$absorption, $\mathrm{K}^{+}$ secretion occurs through the cells of the epithelial lining of the renal tubule, but in COVID-19, uncontrolled $\mathrm{K}^{+}$secretion may induce a hypokalemic condition in infected individuals (Moreno-P et al. 2020) leading to the requirement of ventilation support required by severely infected patients. But a high $\mathrm{K}^{+}$concentration in the blood has an inhibitory role in the RAAS system (Poulsen and Fenton 2019); thus, $\mathrm{K}^{+}$-sparing drugs such as spironolactone is prescribed in few cases as an alternative way of combating SARS-CoV-2 by bypassing the adverse effects of ARBs and ACE (Cadegiani et al. 2020).

In another article (Gumashta and Gumashta 2020), it is suggested that AT2R agonists might be a way to reduce the severity of the patients. Thus, it is well implicated that the ANG III/AT2R might be a new axis to be considered in drug designing.

The aforementioned $\mathrm{K}^{+}$-sparing diuretics do not only increase $\mathrm{K}^{+}$reabsorption (Cadegiani et al. 2020) but may also increase $\mathrm{Na}^{+}$secretion by blocking the ENaCs (Fang et al. 2020). Amiloride, a potent potassium-sparing diuretic, has multivariate potential as it not only suppresses the $\mathrm{ENaC}$ activity (Bhagatwala et al. 2014) but also has a direct effect in reducing blood pressure,cardiovascular risks, and often edema observed during COVID infection (Hinrichs et al. 2018). Since aldosterone blockers might hamper the activity of ACE2 (Fang et al. 2020), ENaC-blocking drugs might be another bypass to adverse coronary effects. Research on SARS-CoV-2 survivors with chronic hypertension and without any hypertension is yet to be done, though ACE2 modulation may affect them in the future.

Despite such a lack of knowledge of the risk of recurrence of Covid-19, long-term effects of medication and weakened immunity may trigger the infection again. However, reinfection of SARS-CoV-2 is still unknown. Also, the possibility of reinfection with SARS-CoV-2 is poorly understood. However, some recent works have found two distinct significant genetic variants of SARS-CoV-2 infection in the same individual and were reported to be a case of reinfection of SARS-CoV-2 (Tillett et al. 2020). But as such, the possibility of reinfection with SARS-CoV-2 is not well understood. Apart from vaccines, alternative medicines are available, and new medication with low side effects and preventive organ effects in this extraordinary situation may find a possible way out.

\section{Conclusion}

This review highlights how SARS-CoV-2 infection in synergy with the RAAS axis can inflict the modulation of the RAAS axis. Furthermore, this complex loop interdependence between RAAS and SARS-CoV-2 gets more complicated as apparent in several pathophysiological conditions like diabetes; RAAS axis modulated by immunosuppressive conditions may accelerate the infectivity of SARS-CoV-2 because these diseases are known to raise the comorbidity. Overall, the present review implies how COVID patients bear the alteration in their RAAS axis and, therefore, changes in the physiological and behavioral aspects are brought about. Chronic hypertensive individuals can be more susceptible to recurrence of the disease than the normal ones (Clark et al. 2021). Reinfection might be another problem that may arise in the future with a different and possibly more lethal strain of the SARS-CoV-2 virus.

The development of new target-specific drugs against hypertension, i.e., less dependent on ACE2, is vital. Other than that, modifying ACE2 levels or activity in the target cells is highly solicited. Though this review ceases to show any reports of hypertension in COVID-19 survivors, active involvement of RAAS might be a possibility in triggering hypertension in high-risk groups of the population. Infected patients may bear the alteration in blood pressure and hypertension state through CoV-2-mediated RAAS alteration; therefore, it is imperative to develop a conjugated approach to directional and hypertension therapy in a synergistic approach. Several reports established that hypertension and the RAAS axis bear the potential role in the pathogenicity of SARS-CoV-2 infection (Mancia et al. 2020; Jarari et al. 2016). Also, several studies and trials are underway on how the RAAS inhibitors could modulate the infectivity of SARS-CoV-2 (Zhang et al. 2020; Vaduganathan et al. 2020).

The identification and characterization of the specific drug target area and mechanism against SARS-CoV-2 remain an enigma to us, as is the role of antihypertensive drugs such as AREi and ARBs. Besides this, the possible mechanism behind the ACE2 modulator drugs or drug-induced modulation in $\mathrm{K}^{+}$ and how they are involved in the possible lowering of the 
SARS-CoV-2 infection is still an area that requires clarity. Along with the infection of SARS-CoV-2, simultaneous modulation of the RAAS axis occurs as it targets the ACE2 receptor, which in turn remains an integral part of the RAAS axis. While the COVID-19 virus manifestations persist, there is a modulated RAAS axis posing immediate or post-COVID-19 threats for a prolonged time. This observation has not been focused upon and needs in-depth investigation or otherwise may culminate into neglect of significance.

Possibly, along with the therapy against SARS-CoV-2, researchers must strategize solutions to the alteration in the RAAS axis simultaneously by providing an array of opportunities to reduce the severity and comorbidity in COVID-19 patients achieved through the designing of competent drugs. At this point, the possible drug target area against SARS-CoV-2 is still unclear to us. The same is true about the role of antihypertensive medications such as AREi and ARBs. The possible mechanism of ACE2 modulator drugs or drug-induced modulation in $\mathrm{K}^{+}$ and how they are involved in lowering the SARS-CoV-2 infectivity is still an area under investigation.

\section{Data and materials availability Yes}

Author contribution Mr. Rohit Sen designed the framework of the review article and prepared the manuscript. Dr. Devashish Sengupta provided inputs about the biochemical and drug-related aspects of the review. Dr. Avinaba Mukherjee supervised the entire manuscript preparation and hypothesized the possible drug target area.

\section{Declarations}

Ethics approval Not applicable

Consent to participate Yes

Consent for publication Yes

Competing interests None to declare.

\section{References}

Akhtar S, Benter IF, Danjuma MI, Doi SAR, Hasan SS, Habib AM (2020) Pharmacotherapy in COVID-19 patients: a review of ACE2-raising drugs and their clinical safety. J Drug Target 28:78. https://doi.org/10.1080/1061186x.2020.1797754

Armaly Z, Kinaneh S, Skorecki K (2021) Renal manifestations of Covid19: physiology and pathophysiology. J Clin Med 10:1-21. https:// doi.org/10.3390/jcm10061216

Belsky JA, Tullius BP, Lamb MG, Sayegh R, Stanek JR, Auletta JJ (2021) COVID-19 in immunocompromised patients: a systematic review of cancer, hematopoietic cell and solid organ transplant patients. J Infect 82:329-338. https://doi.org/10.1016/j.jinf.2021.01. 022

Bhagatwala J, Harris RA, Parikh SJ, Zhu H, Huang Y, Kotak I, Seigler N, Pierce GL, Egan BM, Dong Y (2014) Epithelial sodium channel inhibition by amiloride on blood pressure and cardiovascular disease risk in young pre hypertensives. J Clin Hypertens 16:47-53. https:// doi.org/10.1111/jch.12218

Burrell LM, Johnston CI, Tikellis C, Cooper ME (2004) ACE2, a new regulator of the renin-angiotensin system. Trends Endocrinol Metab 15(4):166-169. https://doi.org/10.1016/j.tem.2004.03.001

Cadegiani FA, Goren A, Wambier CG (2020) Spironolactone may protect SARS-CoV-2: targeting androgens, angiotensin-converting enzyme 2 (ACE2), and renin-angiotensin-aldosterone system (RAAS). Med Hypotheses 143:110112. https://doi.org/10.1016/j.mehy.2020. 110112

Chaudhry F, Lavandero S, Xie X, Sabharwal B, Zheng YY (2020) Manipulation of ACE2 expression in COVID-19. Open Heart 7(2):e001424. https://doi.org/10.1136/openhrt-2020-001424

Chu C, Zeng S, Hasan AA, Hocher CF, Krämer BK, Hocher B (2021) Comparison of infection risks and clinical outcomes in patients with and without SARS-CoV-2 lung infection under renin-angiotensinaldosterone system blockade: systematic review and meta-analysis. Br J Clin Pharmacol 87:2475-2492. https://doi.org/10.1111/bcp. 14660

Clark CE, McDonagh STJ, McManus RJ, Martin U (2021)COVID-19 and hypertension: risks and management. A scientific statement on behalf of the British and Irish Hypertension Society. J Hum Hypertens 35:304-307. https://doi.org/10.1038/s41371-02000451-x

Del Borgo M, Wang Y, Bosnyak S, Khan M, Walters P, Spizzo I, Perlmutter P, Hilliard L, Denton K, Aguilar MI, Widdop RE, Jones ES (2015) $\beta$-Pro7Ang III is a novel highly selective angiotensin II type 2 receptor (AT2R) agonist, which acts as a vasodepressor agent via the AT2R in conscious spontaneously hypertensive rats. Clin Sci 129:505-513. https://doi.org/10.1042/CS20150077

Dyer O (2021) Covid-19: Study claims real global deaths are twice official figures. BMJ 373:n1188. https://doi.org/10.1136/bmj.n.1188

Fang L, Karakiulakis G, Roth M (2020) Are patients with hypertension and diabetes mellitus at increased risk for COVID-19 infection? Lancet Respir Med 8:e21. https://doi.org/10.1016/S2213-2600(20) 30116-8

Feldman EL, Savelieff MG, Hayek SS, Pennathur S, Kretzler M, PopBusui R (2020)COVID-19 and diabetes: a collision and collusion of two diseases. Diabetes 69:2549-2565

Ferrario CM, Jessup J, Chappell MC (2005) Effect of angiotensinconverting enzyme inhibition and angiotensin II receptor blockers on cardiac angiotensin-converting enzyme2. Circulation 111(20): 2605-2610. https://doi.org/10.1161/circulationaha.104.510461

Gheblawi M, Wang K, Viveiros A, Nguyen Q, Zhong JC, Turner AJ, Raizada MK, Grant MB, Oudit GY (2020) Circ Res 126:14571475. https://doi.org/10.1161/circresaha.120.317015

Gressens SB, Leftheriotis G, Dussaule JC, Flamant M, Levy BI, VidalPetiot E (2021) Controversial roles of the renin angiotensin system and its modulators during the COVID-19 pandemic. Front Physiol 12:624052. https://doi.org/10.3389/fphys.2021.624052

Gumashta J, Gumashta R (2020) Role of the backbenchers of the reninangiotensin system ACE2 and AT2 receptors in COVID-19: lessons from SARS. Cureus 12(6):e8411. https://doi.org/10.7759/cureus. 8411

Gumz ML, Stow LR, Lynch IJ, Greenlee MM, Rudin A, Cain BD, Weaver DR, Wingo CS (2009) The circadian clock protein Period 1 regulates the expression of the renal epithelial sodium channel in mice. J ClinInvest 119(8):2423-2434. https://doi.org/10.1172/ JCI36908

Hair PI, Scott LJ, Perry CM (2007) Fixed-dose combination lercanidipine/enalapril. Drugs 67(1):95-106. https://doi.org/10. 2165/00003495-200767010-00007

Hall JE, da Silva AA, do Carmo JM, Dubinion J, Hamza S, Munusamy S, Smith G, Stec DE (2010) Obesity-induced hypertension: role of sympathetic nervous system, leptin, and melanocortins. J Biol 
Chem 285(23):17271-17276. https://doi.org/10.1074/jbc.R110. 113175

Hall JE, do Carmo JM, da Silva AA, Wang Z, Hall ME (2015) Obesityinduced hypertension: interaction of neurohumoral and renal mechanisms. Circ Res 116:991-1006. https://doi.org/10.1161/circresaha. 116.305697

Hartner A, Cordasic N, Klanke B (2014) Renal protection by low dose irbesartan in diabetic nephropathy is paralleled by a reduction of inflammation, not of endoplasmic reticulum stress. Biochim Biophys Acta 1842:558-565. https://doi.org/10.1016/j.bbadis. 2014.01.001

He L, Ding Y, Zhang Q, Che X, He Y, Shen H, Wang H, Li Z, Zhao L, Geng J, Deng Y, Yang L, Li J, Cai J, Qiu L, Wen K, Xu X, Jiang S (2006) Expression of elevated levels of pro-inflammatory cytokines in SARS-CoV-infected ACE2+ cells in SARS patients: relation to the acute lung injury and pathogenesis of SARS. J Pathol 210(3): 288-297. https://doi.org/10.1002/path.2067

Hinrichs GR, Mortensen LA, Jensen BL, Bistrup C (2018) Amiloride resolves resistant edema and hypertension in a patient with nephrotic syndrome; a case report. Phys Rep 6:e13743. https://doi.org/10. 14814/phy2.13743

Ingraham NE, Barakat AG, Reilkoff R, Bezdicek T, Schacker T, Chipman JG, Tignanelli CJ, Puskarich MA (2020) Understanding the renin-angiotensin- aldosterone-SARS-CoV axis: a comprehensive review. Eur Respir J 56:2000912. https://doi.org/10.1183/ 13993003.00912-2020

Iyer SN, Chappell MC, Averill DB, Diz DI, Ferrari CM (1998) Vasodepressor actions of angiotensin-(1-7) unmasked during combined treatment with lisinopril and losartan. Hypertension 31:699705. https://doi.org/10.1161/01.HYP.31.2.699

Jarari N, Rao N, Peela JR, Ellafi KA, Shakila S, Said AR, Nelapalli NK, Min Y, Tun KD, Jamallulail SI, Rawal AK, Ramanujam R, Yedla RN, Kandregula DK, Argi A, Peela LT (2016) A review on prescribing patterns of antihypertensive drugs. Clinical Hypertension 22:1-8. https://doi.org/10.1186/s40885-016-0042-0

Kai H, Kai M (2020) Interactions of coronaviruses with ACE2, angiotensin II, and RAAS inhibitors - lessons from available evidence and insights into COVID-19. Hypertens Res 43:648-654. https://doi. org/10.1038/s41440-020-0455-8

Kalil GZ, Haynes WG (2012) Sympathetic nervous system in obesityrelated hypertension: mechanisms and clinical implications. Hypertens Res 35:4-16. https://doi.org/10.1038/hr.2011.173

Kaseb AO, Mohamed YI, Malek AE, Raad II, Altameemi L, Li D, Kaseb OA, Kaseb SA, Selim A, Ma Q (2021) The impact of angiotensinconverting enzyme 2 (ACE2) expression on the incidence and severity of COVID-19 infection. Pathogens 10:3. https://doi.org/10. 3390/pathogens10030379

Kawabe Y, Mori J, Morimoto H, Yamaguchi M, Miyagaki S, Ota T, Tsuma Y, Fukuhara S, Nakajima H, Oudit GY, Hosoi H (2019) ACE2 exerts anti-obesity effect via stimulating brown adipose tissue and induction of browning in white adipose tissue. Am J Phys Endocrinol Metab 317:e1140-e1149. https://doi.org/10.1152/ ajpendo.00311.2019

Klemens CA, Edinger RS, Kightlinger L, Li X, Butterworth MB (2017) Ankyrin $\mathrm{G}$ expression regulates apical delivery of the epithelial sodium channel (ENaC). J BiolChem 292(1):375-385. https://doi.org/ 10.1074/jbc.M116.753616

Kleyman TR, Cragoe EJ Jr (1988) The mechanism of action of amiloride. Semin Nephrol 8(3):242-248

Kuba K, Imai Y, Nakanishi TO, Penninger JM (2010) Trilogy of ACE2: a peptidase in the renin-angiotensin system, a SARS receptor, and a partner for amino acid transporters. Pharmacol Ther 128:119-128. https://doi.org/10.1016/j.pharmthera.2010.06.003

Kurihara T, Ozawa Y, Ishida S, Okano H, Tsubota K (2012) Reninangiotensin system hyperactivation can induce inflammation and retinal neural dysfunction. Int J Inflamm 2012:581695. https://doi. org/10.1155/2012/581695

Lavoie JL, Sigmund CD (2003) Minireview: Overview of the reninangiotensin system - an endocrine and paracrine system. Endocrinology 144:2179-2183. https://doi.org/10.1210/en.2003-0150

Layton AM, Eady EA, Whitehouse H, Del Rosso JQ, Fedorowicz Z, van Zuuren EJ (2017) Oral spironolactone for acne vulgaris in adult females: a hybrid systematic review. Am J Clin Dermatol 18:169191. https://doi.org/10.1007/s40257-016-0245-x

Li Y, Cai S, Wang Q, Zhou J, Hou B, Yu H, Ge Z, Guan R, LiuX (2016) Valsartan attenuates intimal hyperplasia inballoon-injured rat aortic arteries through modulating theangiotensin-converting enzyme 2angiotensin-(1-7)-Masreceptor axis. Arch Biochem Biophys 598: 11-17. https://doi.org/10.1016/j.abb.2016.03.028

Lite C, Ahmed SSSJ, Juliet M, Freddy AJ (2021) SARS-CoV-2/human interactome reveals ACE2 locus crosstalk with the immune regulatory network in the host. Pathog Dis 79:1-9. https://doi.org/10.1093/ femspd/ftab005

Liu CX, Hu Q, Wang Y, Zhang W, Ma ZY, Feng JB, Wang R, Wang XP, Dong B, Gao F, Zhang MX, Zhang Y (2011) Angiotensinconverting enzyme (ACE) 2 overexpression ameliorates glomerular injury in a rat model of diabetic nephropathy: a comparison with ACE inhibition. Mol Med 17:59-69. https://doi.org/10.2119/ molmed.2010.00111

Liu Y, Yang Y, Zhang C, Huang F, Wang F, Yuan J, Wang Z, Li J, Li J, Feng C, Zhang Z, Wang L, Peng L, Chen L, Qin Y, Zhao D, Tan S, Yin L, Xu J et al (2020) Clinical and biochemical indexes from 2019-nCoV infected patients linked to viral loads and lung injury. Sci China Life Sci 63:364-374. https://doi.org/10.1007/s11427020-1643-8

Mancia G, Rea F, Ludergnani M, Apolone G, Corrao G (2020) Reninangiotensin-aldosterone system blockers and the risk of Covid-19. N Engl J Med 382:2431-2440. https://doi.org/10.1056/ NEJMoa2006923

Martinez-Rojas MA, Vega-Vega O, Bobadilla NA (2020) Is the kidney a target of SARS-CoV-2? Am J Physiol Renal Physiol 318:F1454 F1462. https://doi.org/10.1152/ajprenal.00160.2020

Miesbach W (2020) Pathological role of angiotensin II in severe COVID19. TH Open 4:e138-e144. https://doi.org/10.1055/s-0040-1713678

Moreno-P O, Ramirez JM, Kenneally L, Perdiguero M, Andres M, Navarro M, Ruiz-Torregrosa P, Boix V, Gil J, Merino E (2020) Hypokalemia as a sensitive biomarker of disease severity and the requirement for invasive mechanical ventilation requirement in COVID-19 pneumonia: a case series of 306 Mediterranean patients. Int J Infect Dis 100: 449-454. https://doi.org/10.1016/j.ijid.2020.09.033

Ni W, Yang X, Yang D, Bao J, Li R, Xiao Y, Hou C, Wang H, Liu J, Yang D, Xu Y, Cao Z, Gao Z (2020) Role of angiotensin-converting enzyme 2 (ACE2) in COVID-19. Crit Care 24:422-432. https://doi. org/10.1186/s13054-020-03120-0

Noreng S, Bharadwaj A, Posert R, Yoshioka C, Baconguis I (2018) Structure of the human epithelial sodium channel by cryo-electron microscopy. Elife 7:e39340. https://doi.org/10.7554/eLife.39340. 001

Oudit GY, Kassiri Z, Jiang C, Liu PP, Poutanen SM, Penninger JM, Butany J (2009) SARS-coronavirus modulation of myocardial ACE2 expression and inflammation in patients with SARS. Eur J Clin Investig 39:618-625. https://doi.org/10.1111/j.1365-2362. 2009.02153.x

Patel VB, Mori J, McLean BA, Basu R, Das SK, Ramprasath T, Parajuli N, Penninger JM, Grant MB, Lopaschuk GD, Oudit GY (2016) ACE2 deficiency worsens epicardial adipose tissue inflammation and cardiac dysfunction in response to diet-induced obesity. Diabetes 65(1):85-95. https://doi.org/10.2337/db15-0399

Patel S, Rauf A, Khan H, Abu-Izneid T (2017) Renin-angiotensinaldosterone (RAAS): the ubiquitous system for homeostasis and 
pathologies. Biomed Pharmacother 94:317-325. https://doi.org/10. 1016/j.biopha.2017.07.091

Peminda KC, Gardner MJ, Sowers JR (2017) The renin angiotensin aldosterone system in obesity and hypertension: roles in the cardiorenal metabolic syndrome. Med Clin N Am 101:129-137. https://doi.org/10.1016/j.mcna.2016.08.009

Poulsen SB, Fenton RA (2019) K+ and the renin-angiotensin-aldosterone system: new insights into their role in blood pressure control and hypertension treatment. J Physiol 597:4451-4464. https://doi. org/10.1113/JP276844

Reaux A, Fournie-Zaluski MC, Llorens-Cortes C (2001) Angiotensin III: a central regulator of vasopressin release and blood pressure. Trends Endocrinol Metab 12(4):157-162. https://doi.org/10.1016/S10432760(01)00381-2

Ribeiro-Oliveira A Jr, Nogueira AI, Pereira RM, Boas WWV, Santos RAS, Silva ACS (2008) The renin-angiotensin system and diabetes: an update. Vasc Health Risk Manag 4(4):787-803

Richards J, Greenlee MM, Jeffers LA, Cheng KY, Guo L, Eaton DC, Gumz ML (2012) Inhibition of $\alpha \mathrm{ENaC}$ expression and ENaC activity following blockade of the circadian clock-regulatory kinases

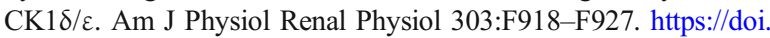
org/10.1152/ajprenal.00678.2011

Savoia A, Arrabito E, Parente R, Nicoletti C, Madaro L, Battistoni A, Filippini A, Steckelings UM, Touyz RM, Volpe M (2020) Mas receptor activation contributes to the improvement of nitric oxide bioavailability and vascular remodeling during chronic AT1R (angiotensin type-1 receptor) blockade in experimental. Hypertension 76:1753-1761. https://doi.org/10.1161/hypertensionaha.120.15527

Schütten MTJ, Houben AJHM, de Leeuw PW, Stehouwer CDA (2017) The link between adipose tissue renin-angiotensin-aldosterone system signaling and obesity-associated hypertension. Physiology 32: 197-209. https://doi.org/10.1152/physiol.00037.2016

Soler MJ, Wysocki J, Batlle D (2013) ACE2 alterations in kidney disease. Nephrol Dial Transplant 28:2687-2697. https://doi.org/10.1093/ ndt/gft320

Strawn WB, Ferrario CM, Tallant EA (1999) Angiotensin-(1-7) reduces smooth muscle growth after vascular injury. Hypertension 33:207211. https://doi.org/10.1161/01.hyp.33.1.207

Sumners C, de Kloet AD, Krause EG, Unger T, Steckelings UM (2015) Angiotensin type 2 receptors: blood pressure regulation and endorgan damage. Curr Opin Pharmacol 21:115-121. https://doi.org/ 10.1016/j.coph.2015.01.004

Tikellis C, Thomas MC (2012)Angiotensin-converting enzyme 2 (ACE2) Is a key modulator of the renin angiotensin system in health and disease. Int J Pept 2012:1-8. https://doi.org/10.1155/2012/256294

Tillett RL, Sevinsky JR, Hartley PD, Kerwin H, Crawford N, Gorzalski A, Laverdure C, Verma SC, Rossetto CC, Jackson D, Farrell MJ, Hooser SV, Pandori M (2020) Genomic evidence for reinfection with SARS-CoV-2: a case study. Lancet Infect Dis 21:52-58. https://doi.org/10.1016/S1473-3099(20)30764-7

Timmermans PB, Duncia JV, Carini DJ, Chiu AT, Wong PC, Wexler RR, Smith RD (1995) Discovery of losartan, the first angiotensin II receptor antagonist. J Hum Hypertens 5:S3-S18

Toma I, Kang JJ, Sipos A, Vargas S, Bansal E, Hanner F, Meer E, PetiPeterdi J (2008) Succinate receptor GPR91 provides a direct link between high glucose levels and renin release in murine and rabbit kidney. Clinical Investigation 118:2526-2534. https://doi.org/10. 1172/JCI33293
Undurraga EA, Chowell G, Mizumoto K (2021) COVID-19 case fatality risk by age and gender in a high testing setting in Latin America: Chile March-August 2020. Infect Dis Poverty 10:1-11. https://doi. org/10.1186/s40249-020-00785-1

Vaduganathan M, Vardeny O, Michel T, McMurray JJV, Pfeffer MA, Solomon SD (2020) Renin-angiotensin-aldosterone system inhibitors in patients with Covid-19. N Engl J Med 382:1653-1659. https://doi.org/10.1056/NEJMsr2005760

Vandenbeuch A, Kinnamon SC (2020) Is the amiloride-sensitive Na+ channel in taste cells really ENaC? Chem Senses 45:233-234. https://doi.org/10.1093/chemse/bjaa011

Villard O, Morquin D, Molinari N, Raingeard I, Nagot N, Cristol JP, Jung B, Roubille C, Foulongne V, Fesler P, Lamure S, Taourel P, Konate A, Maria ATJ, Makinson A, Bertchansky I, Larcher R, Klouche K, Moing VL et al (2020) The plasmatic aldosterone and C-reactive protein levels, and the severity of Covid-19: the Dyhor-19 study. J Clin Med 9:1-12. https://doi.org/10.3390/jcm9072315

Wood JM, Maibaum J, Rahuel J, Grutter MG, Cohen NC, Rasetti V, Rüger H, Göschke R, Stutz S, Fuhrer W, Schilling W, Rigollier P, Yamaguchi Y, Cumin F, Baum HP, Schnell CR, Herold P, Mah R, Bedigian MP (2003) Structure-based design of aliskiren, a novel orally effective renin inhibitor. Biochem Biophys Res Commun 308:698-705. https://doi.org/10.1016/s0006-291x(03)01451-7

Woolf SH, Chapman DA, Sabo RT, Zimmerman EB (2021) Excess deaths from covid-19 and other causes in the US, March 12020 to January 2 2021. JAMA 325:1786-1789. https://doi.org/10.1001/ jama.2021.5199

Xie C, Li Q, Li L, Peng X, Ling Z, Xiao B, Feng J, Chen Z, Chang D, Xie L, Dela Cruz CS, Sharma L (2021) Association of early inflammation with age and asymptomatic disease in COVID-19. J Inflamm Res 14:1207-1216. https://doi.org/10.2147/jir.S304190

Yan W, Spruce L, Rosenblatt MM, Kleyman TR, Rubenstein RC (2007) Intracellular trafficking of a polymorphism in the $\mathrm{COOH}$ terminus of the $\alpha$-subunit of the human epithelial sodium channel is modulated by casein kinase 1. Am J Physiol Renal Physiol 293(3):F868F876. https://doi.org/10.1152/ajprenal.00194.2007

Yang J, Ma Z, Lei Y (2021) A meta-analysis of the association between obesity and COVID-19. Epidemiol Infect 149:E11. https://doi.org/ $10.1017 / \mathrm{S} 0950268820003027$

Ye M, Wysocki J, William J, Soler MJ, Cokic I, Batlle D (2006) Glomerular localization and expression of angiotensin-converting enzyme 2 and angiotensin-converting enzyme: implications for albuminuria in diabetes. J Am Soc Nephrol 17:3067-3075. https://doi. org/10.1681/ASN.2006050423

Yehualashet AS, Belachew TF (2020) ACEIs and ARBs and their correlation with COVID-19: a review. Infect Drug Resist 13:3217-3224. https://doi.org/10.2147/idr.s264882

Zhang J, Wang M, Ding W, Wan J (2020) The interaction of RAAS inhibitors with COVID-19: current progress, perspective and future. Life Sci 257:118142. https://doi.org/10.1016/j.lfs.2020.118142

Zhang X, Lewis AM, Moley JR, Brestoff JR (2021) A systematic review and meta-analysis of obesity and COVID-19 outcomes. Sci Rep 11: 7193. https://doi.org/10.1038/s41598-021-86694-1

Publisher's note Springer Nature remains neutral with regard to jurisdictional claims in published maps and institutional affiliations. 